\title{
Histochemical and Ultrastructural Studies on Pancreatic A Cells. Evidence for Glucagon and Non-Glucagon Components of the $\alpha$ Granule
}

\author{
G. Bussolati, C. Capella, G. Vassallo and E. Solcia
}

Pathological Anatomy II, University of Turin (Prof. Dr. A. Stramignoni) and Pathological Anatomy, University of Pavia (Prof. Dr. L. Mosca) Italy

Received: September 21, accepted: March 18, 1971

\begin{abstract}
Summary. Glucagon-storing cells were detected in the pancreatic islets of horse, guinea pig, rabbit, rat, dog and man by means of indirect immuno-histochomical procedures using fluorescein or peroxidase as markers of antiglucagon sera. By subsequently staining horse islets with selective staining techniques for A, B or D cells, it was directly ascertained that only A cells reacted to antiglucagon sera. A comparison of methods known to stain $\alpha$ granules with immuno-histochemical methods, as well as in vitro experiments on natural and synthetic glucagon, showed that the xanthydrol method, and perhaps also the $o$-phthalaldehyde method, should be regarded as specific histochemical tests for glucagon whereas the HCl-basic dye technique and phosphotungstic haematein should be considered as unspecific glucagon -staining methods, and Grimelius' silver as a method likely to be unrelated to glucagon. In ultrastructural investigations on the human pancreas, the core of the $\alpha$ granule heavily reacted to phosphotungstic acid and peroxidase-marked antiglucagon antibodies, while being unreactive to Grimelius' silver; conversely, the peripheral halo of the $\alpha$ granule heavily reacted to Grimelius' silver, while being poorly reactive or unreactive to phosphotungstic acid and anti-glucagon antibodies. Thus, both light and electron microscopy findings point to a structural and chemical hetereogeneity of the $\alpha$ granule.
\end{abstract}

Etudes histochimiques et ultrastructurales des cellules pancréatiques $A$. Preuves de la présence de constituants glucagoniques et non-glucagoniques dans les granules $\alpha$

Résumé. Des cellules stockant du glucagon ont été détectées dans les îlots pancréatiques du cheval, du cobaye, du lapin, du rat, du chien et de l'homme au moyen de procédés immuno-histochimiques indirects utilisant la fluorescéine ou la peroxydase comme marqueurs des sérums anti-glucagon. En colorant les îlots des chevaux avec des techniques de coloration sélectives pour les cellules A, B ou D, il a été directement prouvé que seules les cellules A réagissent aux sérums anti-glucagon. Une comparaison entre les méthodes connues pour colorer les granules $\alpha$ et les méthodes immuno-histochimiques, ainsi que les expériences in vitro sur le glucagon naturel et synthétique, ont montré que la méthode au xanthydrol et peut-être également la méthode à l'o-phtalaldéhyde, doivent être considérées comme des tests histochimiques spécifiques pour le glucagon; par contre la technique à l'HCl-colorant basique et l'hématéine phosphotungstique doivent être considérées comme des méthodes de coloration non spécifiques pour le glucagon, et la méthode à l'argent de Grimelius probablement comme ne concernant pas le glucagon. Au cours d'investigations ultrastructurales sur le pancréas humain, le centre des granules $\alpha$ réagissait fortement à l'acide phosphotungstique et aux anticorps anti-glucagon marqués à la peroxydase, alors qu'il ne réagissait pas à l'argent de Grimelius; inversement le halo périphérique des granules $\alpha$ réagissait fortement à l'argent de Grimelius, et réagissait peu ou pas à l'acide phosphotungstique et aux anticorps anti-glucagon. Ainsi, les résultats à la fois de microscopie optique et électronique indiquent une hétérogénéité structurale et chimique des granules $\alpha$.

Histochemische und ultrastrukturelle Untersuchungen über die A Zellen der Bauchspeicheldrüse. Nachweis von Glucagon und nicht-Glucagon Anteilen des $\alpha$-Granulums

Zusammenfassung. Die Glucagon enthaltenden Zellen werden in der Bauchspeicheldrüse von Pferd, Meerschweinchen, Kaninchen, Ratte, Hund und Mensch durch immunhistochemische, indirekte Techniken mit Fluorescein- oder Peroxidase-Markierung von Anti-GlucagonAntikörpern lokalisiert. Durch aufeinanderfolgende Färbungen der Langerhansschen Inseln von Pferden mit spezifischen für die $\mathrm{A}, \mathrm{B}$ und $\mathrm{D}$ Zellen histologischen $\mathrm{Me}$ thoden, wurde bewiesen, daß nur die A Zellen mit AntiGlucagon-Antikörpern reagierten. Eine Gegenüberstellung der für die Färbung des $\alpha$-Granulums bekannten Methoden, mit den immunhistochemischen Methoden, und den als in vitro Untersuchungen über synthetisches :und natürliches Glucagon, haben bewiesen, daß die Xanthydrol-Methode, und vielleicht auch die o-PhtalaldehydMethode, für das Glucagon spezifische Methoden darstellen, während die HCl-basischen Farbstoffe und die Phosphorwolframsäure-Hämatin Methoden, als unspezifische Färbemethoden für das Glucagon angesehen werden müssen; die Silbermethode nach Grimelius scheint nicht zum Glucagon in Beziehung zu stehen. In ultrastrukturellen Untersuchungen über die menschliche Bauchspeicheldrüse, reagierte das Zentrum (core) des Granulums stark auf die Phosphorwolframsäure und auf die mit Peroxidase markierten Anti-Glucagon-Antikörper, dagegen reagierte es nicht mit der Silbermethode nach Grimelius. Andererseits reagierte der periphere Hof des $\alpha$ Granulums wenig, oder überhaupt nicht mit der Phosphorwolframsäure und den Anti-Glucagon-Antikörpern. Daher zeig'en die Ergebnisse von Licht- und Elektronenmikroskopie eine chemische und strukturelle Ungleichartigkeit $\operatorname{des} \alpha$-Granulums.

Key-words: Pancreatic islets, A cells, glucagon, immuno-histochemistry, $\alpha$-granule stains, xanthydrol, o-phthalaldehyde, HCl-basic dye, phosphotungstic acid, Grimelius' silver, electron histochemistry. 
The production of glucagon by the non-B cells of the pancreatic islets has been fully proven; moreover, the involvement of A cells has been suggested, and that of $\mathrm{D}$ cells excluded, on the ground of several histochemical and experimental findings (Bencosme et al., 1955; Glenner and Lillie, 1957; Baum et al., 1962; Petersson and Hellman, 1963; Cavallero et al., 1968; Lomsky et al., 1968; Okada et al., 1968; Lange, 1970). However, an extensive direct comparison on the same section of the immuno-histochemical patterns with those of selective stainings for the three islet cell types has not been performed. Of the various staining methods for $\alpha$ granules, only the immuno-histochemical one is usually regarded as fully specific for glucagon. The other methods are considered to be either of limited specificity (as for instance the "tryptophan" tests) or unspecific in respect to the glucagon molecule (as the HCl-basic dye method, phosphotungstic haematein and acid dyes) or of obscure histochemical meaning (as the o-phthalaldehyde and silver impregnation techniques).

An investigation has been undertaken on: 1) the staining of glucagon-storing cells with specific immunohistochemical techniques and the identification of these same cells with methods known selectively to detect islet cell types, and 2) the significance of the various methods for $\alpha$ granules in respect of the histochemistry of glucagon and the fine structure of $\alpha$ granules.

\section{Material and Methods}

\section{a) Immuno-histochemical investigations}

Anti-glucagon antibodies were obtained from 2 adult albino rabbits injected 6 times, at 3 week intervals, with glucagon (beef-pork, crystalline, supplied by E. Lilly, Indianapolis - lot No. 258-234 B-167-1). The first 4 subcutaneous injections were made according to the technique previously employed by Okada et al. (1968). The last 2 injections were done intravenously, by administering $3 \mathrm{mg}$ of glucagon in $1 \mathrm{ml}$ of physiological saline buffered to $\mathrm{pH} 8,+0.05 \mathrm{ml}$ of a solution containing $11 \%$ poly-methyl-metacrilate particles (Bofors). The animals were bled 5 days after the final injection.

In addition, we employed an anti-glucagon rabbit serum, kindly supplied by Dr. R. Lomsky (Charles University, Hradec Kralové, Czechoslovakia).

Indirect "sandwich" immunofluorescence tests were performed using a fluorescent goat anti-rabbit gamma globulin serum, prepared as previously described (Bussolati and Pearse, 1970). Controls were made by omitting the anti-glucagon serum or substituting normal rabbit serum.

Absorption tests were done, to test the specificity of the immunological reaction, by absorbing the antiglucagon serum with $1 \mathrm{mg} / \mathrm{ml}$ of insulin (Squibb) or glucagon (E. Lilly). In immunofluorescence experiments the sera absorbed with insulin gave results similar to those of non-absorbed sera, whereas absorption with glucagon resulted in complete inhibition of the A cell staining.

Immunofluorescence tests were performed on paraffin sections obtained from blocks of horse, guinea pig, rat, dog and human pancreas fixed a) with $4 \%$ formaldehyde in $0.1 \mathrm{M}$ phosphate buffer $\mathrm{pH} 7.4$ at $4^{\circ} \mathrm{C}$ for at least $24 \mathrm{~h}$, or b) with Carnoy's fluid at room temp. for $1 \mathrm{~h}$.

An indirect immuno-histochemical procedure employing Peroxidase as a marker, similar in principle to that described by Avrameas (1969) was carried out by the successive exposure of sections to: 1) rabbit antiglucagon sera; 2) goat anti-rabbit gamma globulin sera; 3) pure rabbit anti-peroxidase antibodies binding free antibody sites of the anti-rabbit gamma globulin antibodies); 4) peroxidase (grade 1, Boehringer and type VI, Sigma), diluted as suggested by Mason et al. (1969). After staining with 3-3' diamino-benzidine (Sigma) according to the method of Graham and Karnovsky (1966) for peroxidase activity, sections were treated with $1 \% \mathrm{OsO}_{4}$, and either a) mounted in balsam for light microscopic examination, or b) observed unmounted under the light microscope and then resin-embedded for electron microscopy. Controls were performed by substituting normal rabbit sera for the anti-glucagon sera. Paraffin ( $5 \mu$ thick) or cryostat (20 $\mu$ thick) sections of human, horse and guinea pig pancreas fixed at $4^{\circ} \mathrm{C}$ in $4 \%$ formaldehyde buffered to $\mathrm{pH} 7.4$ were used in this procedure.

Staining procedures. Horse pancreatic islets, after immunofluorescence staining, were photographed. The sections were subsequently refixed for $24 \mathrm{~h}$ at room temperature with $4 \%$ formaldehyde or $5 \%$ glutaraldehyde in $0.1 \mathrm{M}$ phosphate buffer $\mathrm{pH} 7.4$ or with GPA mixture (Solcia et al., 1968) and restained with aldehyde fuchsin for B cells (Scott, 1952), coryphosphine $\mathrm{O}$ for D and B cells (Bussolati et al., 1969; Bussolati, unpublished observations) HCl-toluidine blue (HCl$\mathrm{TB}$ ) and HCl-lead-haematoxylin (HCl-PbH) for A and D cells (Solcia et al., 1968 and 1969 b), oxidationphosphotungstic haematein (ox-PTH) for A cells (Caramia et al., 1965; Cavallero and Solcia, 1968), Grimelius' silver for A cells (Grimelius, 1968) or xanthydrol test for A cells (Cavallero et al., 1968).

b) Histologic investigations

Samples from pancreas of horses, guinea pigs, rats, rabbits, dogs and men were fixed for 1 to 4 days at $4{ }^{\circ} \mathrm{C}$ or at room temperature with $4 \%$ formaldehyde, $5 \%$ glutaraldehyde or $2.5 \%$ formaldehyde $+2.5 \%$ glutaraldehyde in $0.1 \mathrm{M}$ phosphate buffer $\mathrm{pH} 7.4$, and with Bouin's fluid, Carnoy's fluid or GPA mixture (Solcia et al., 1968). To paraffin sections from such material, the following $\alpha$ granule methods were applied: "indole" tests with special reference to the xanthydrol method (Lillie, 1957; Solcia et al., 1969a), phosphotungstic haematein, with or without previous acid permanganate oxidation of tissue sections, known to stain basic groups of polypeptides and proteins 
(Terner et al., 1964), toluidine blue, coryphosphine 0 and lead-haematoxylin, with or without previous $\mathrm{HCl}$ treatment of sections, known to stain acid groups, particularly side-chain protein or polypeptide carboxyls (Solcia et al., 1968 and 1969; Bussolati et al., 1969) and Grimelius' silver impregnation (Grimelius, 1968). The $o$-phthalaldehyde (OPT) method of Takaya (1970) was applied to both fresh cryostat sections and formaldehyde- or Carnoy-fixed cryostat or paraffin sections.

\section{c) Electron microscopy investigations}

Small samples of human pancreatic tissue were fixed at $4^{\circ} \mathrm{C}$ for 3 to 24 hours in $4 \%$ formaldehyde,
$2.5 \%$ glutaraldehyde or $2.5 \%$ formaldehyde $+2.5 \%$ glutaraldehyde in $0.1 \mathrm{M}$ phosphate buffer $\mathrm{pH} 7.4$, postfixed in osmium tetroxide and embedded in Epon 812 (Luft, 1961). Thin sections were stained with uranyl acetate and lead citrate (Venable and Coggeshall, 1965). Some aldehyde-fixed specimens were silver impregnated according to the Grimelius technique (Vassallo et al, 1971) or stained 2 hours at $37^{\circ} \mathrm{C}$ with $2 \%$ phosphotungstic acid (PT) in distilled water; then they were dehydrated and resin-embedded. To localize glucagon at E.M. level, an indirect immuno-histochemical procedure using peroxidase as marker was applied to cryostat sections of formaldehyde-fixed specimens (see $a$ ).
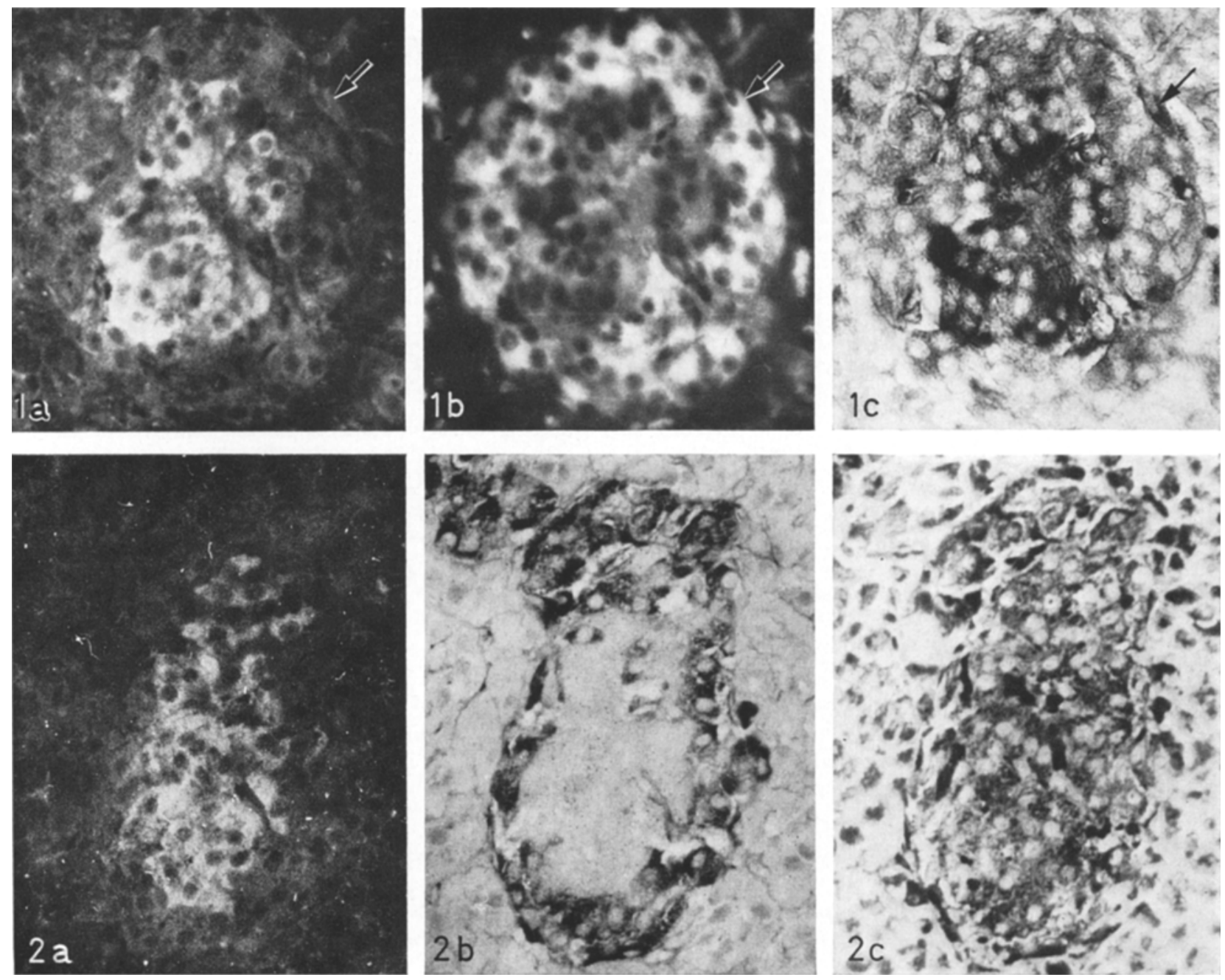

Fig. 1a, b and c. Formaldehyde-fixed horse pancreatic islet successively stained with fluoresceinated anti-glucagon antibodies (a), coryphosphine $\mathbf{0}(\mathrm{b})$, and HCl-toluidine blue (c). Centrally located A cells are reactive in $a$ and $c$ (blue), practically unreactive in $b$; a D cell at the periphery of the islet (arrow) is reactive in $b$ and $c$ (red) but fails to react to anti-glucagon antibodies in $a$. $\times 280$

Fig. 2a, b and c. Formaldehyde-fixed horse pancreatic islet successively stained with fluoresceinated anti-glucagon antibodies (a), aldehyde fuchsin (b), and phosphotungstic haematein (c). A cells are reactive in $a$ and $c$, unreactive in $b ; \mathrm{B}$ cells are reactive in $b$, keep in $c$ part of their aldehyde-fuchsin staining of step $b$, but are unreactive to anti-glucagon antibodies in $a . X 280$ 
d) In vitro tests

These were done by scattering synthetic (both crystalline and lyophilized synthetic glucagon, kindly supplied by Dr. E. Wunsch and coworkers, MaxPlanck-Institut fur Eiweiss- und Lederforschung, München) or natural glucagon (beef-pork crystalline glucagon, lots No 258-561 b-180 and No 258-234 B-167-1, kindly supplied by E. Lilly, Indianapolis, and twice crystallized pork glucagon lot No B 66, kindly supplied by Novo 'Terapeutisk Laboratorium, Copenhagen) in a gelatine-sorbitol film on slides; part of these slides were plunged in the same fixing mixtures used in histological procedures. Both fixed and unfixed slides were stained just as tissue sections.

\section{Results}

A) Reaction of horse islets cells to antiglucagon sera. As already noted, (Hellman et al., 1962; Solcia and Sampietro, 1965), horse pancreatic islets usually conversely, Grimelius' silver gave intense impregnation in all species, perhaps even more intense in man and dog than in the other mammals. Immunofluorescence, OPT, PTH with or without previous oxidation, $\mathrm{HCl}$ TB and $\mathrm{HCl}-\mathrm{PbH}$, although always giving heavier stainings than indole tests, seemed to parallel better the behaviour of the last methods than that of Grimelius' silver (Figs. 3-6).

The behaviour of immunofluorescence, OP'T, PTH and Grimelius' silver in staining formaldehyde- or Carnoy-fixed horse A cells is illustrated in Table 2; results obtained by staining guinea pig A cells in Bouin-fixed sections treated with hot $\mathrm{HCl}$ are reported. in Table 3. In both cases Grimelius' silver behaved quite differently from other methods.

C) In experiments in vitro both fixed and unfixed natural or synthetic glucagon reacted blue-gray to xanthydrol and blue-violet to PTH, and fluoresced intensely with OPT, just as pancreatic $\alpha$ granules did. Conversely, glucagon failed to react to Grimelius' silver.

Table 1. Reaction of formaldehyde-fixed horse islet cell types to fuorescein-labelled antiglucagon serum and selective granule stains

\begin{tabular}{llllllll}
\hline Cell types & $\begin{array}{l}\text { Aldehyde- } \\
\text { fuchsin }\end{array}$ & $\begin{array}{l}\text { Corypho- } \\
\text { sphine }\end{array}$ & HCl-TB & HCl-PbH & $\begin{array}{l}\text { Oxidation- } \\
\text { PTH }\end{array}$ & $\begin{array}{l}\text { Grimelius' } \\
\text { silver }\end{array}$ & $\begin{array}{c}\text { Xanthydrol Antigluca- } \\
\text { gon sera }\end{array}$ \\
\hline A cells & - & - & $\begin{array}{l}+++ \\
\text { blue-violet }\end{array}$ & +++ & +++ & +++ & ++ \\
B cells & +++ & ++ & - & - & - & - & - \\
D cells & - & +++ & $\begin{array}{l}+++ \\
\text { red }\end{array}$ & ++++ & - & + & - \\
\hline
\end{tabular}

showed groups of A cells in the centre, surrounded by $B$ cells; elongated D cells were scattered at the extreme periphery of the islets. This peculiar pattern was of great help in identifying fluorescent and non-fluorescent cells of restained sections. As shown in Table 1 and Figs. 1 and 2, neither B nor D cells were stained by the immuno-histochemical methods employing antiglucagon sera. Groups of immunofluorescent, glucagonstoring sells were located in the centre of the islets; the same cells were subsequently stained blue with ox-PTH, blue-violet with HCl-TB, blue-black with $\mathrm{HCl}-\mathrm{PbH}$, black with Grimelius' silver and blue-gray with xanthydrol. Such staining pattern is known to be peculiar to A cells. Immunofluorescence controls gave completely negative results.

$\hat{A}$ cells were also stained with the immuno-histochemical method employing peroxidase as marker. The reaction product was dark brown and apparently granular (Fig. 7).

B) Comparison of glucagon stains to other $\alpha$-granule methods. A cells of the various species investigated showed different degrees of reactivity to granulestaining methods. For instance, human, rat and $\operatorname{dog} \alpha$ granules reacted poorly to indole tests, whereas horse, guinea-pig or rabbit granules gave heavier staining;
Table 2. Influence of formaldehyde or Carnoy fixation on the staining of horse a granules

\begin{tabular}{lllll}
\hline Fixation & $\begin{array}{l}\text { Immuno- } \\
\text { fluorescence }\end{array}$ & OPT & PTH & $\begin{array}{l}\text { Grimelius' } \\
\text { silver }\end{array}$ \\
\hline $\begin{array}{l}\text { Formalde- } \\
\text { hyde }\end{array}$ & +++ & +++ & +++ & +++ \\
Carnoy & +++ & +++ & +++ & - \\
\hline
\end{tabular}

Table 3. Influence of $\mathrm{HCl}\left(0.2 \mathrm{~N}\right.$ at $60^{\circ} \mathrm{C}$ for 3 hours $)$ on the staining of Bouin-fixed guinea-pig a granules

\begin{tabular}{|c|c|c|c|c|}
\hline $\begin{array}{l}\text { Pretreat- } \\
\text { ment of } \\
\text { sections }\end{array}$ & Xanthydrol & $\mathrm{TB}$ & $\mathrm{PbH}$ & $\begin{array}{l}\text { Grimelius' } \\
\text { silver }\end{array}$ \\
\hline$\overline{\mathrm{HCl}}$ & $\begin{array}{l}++ \\
++\end{array}$ & $\stackrel{ \pm}{+}++$ & $\stackrel{ \pm}{+++}$ & +++ \\
\hline
\end{tabular}

D) Ultrastructural studies. The application of Grimelius' silver and PT to specimens processed for ultrastructural investigations gave an opportunity to compare directly light and electron microscopy findings. As shown by Terner et al. (1964), light microscopy staining of tissues with PTH is essentially due to PT; 
moreover, $\mathrm{PT}$ is known to give high electron contrast to glucagon fibrils (Davies, 1968).

The ultrastructural findings in human A cells resembled that already deseribed (Like, 1967; Shiba- saki and Ito, 1969). In particular $\propto$ granules showed two components, the core and the peripheral halo, whose staining patterns (see Table 4 and Fig. 8) were quite different. Despite poor penetration of antibodies
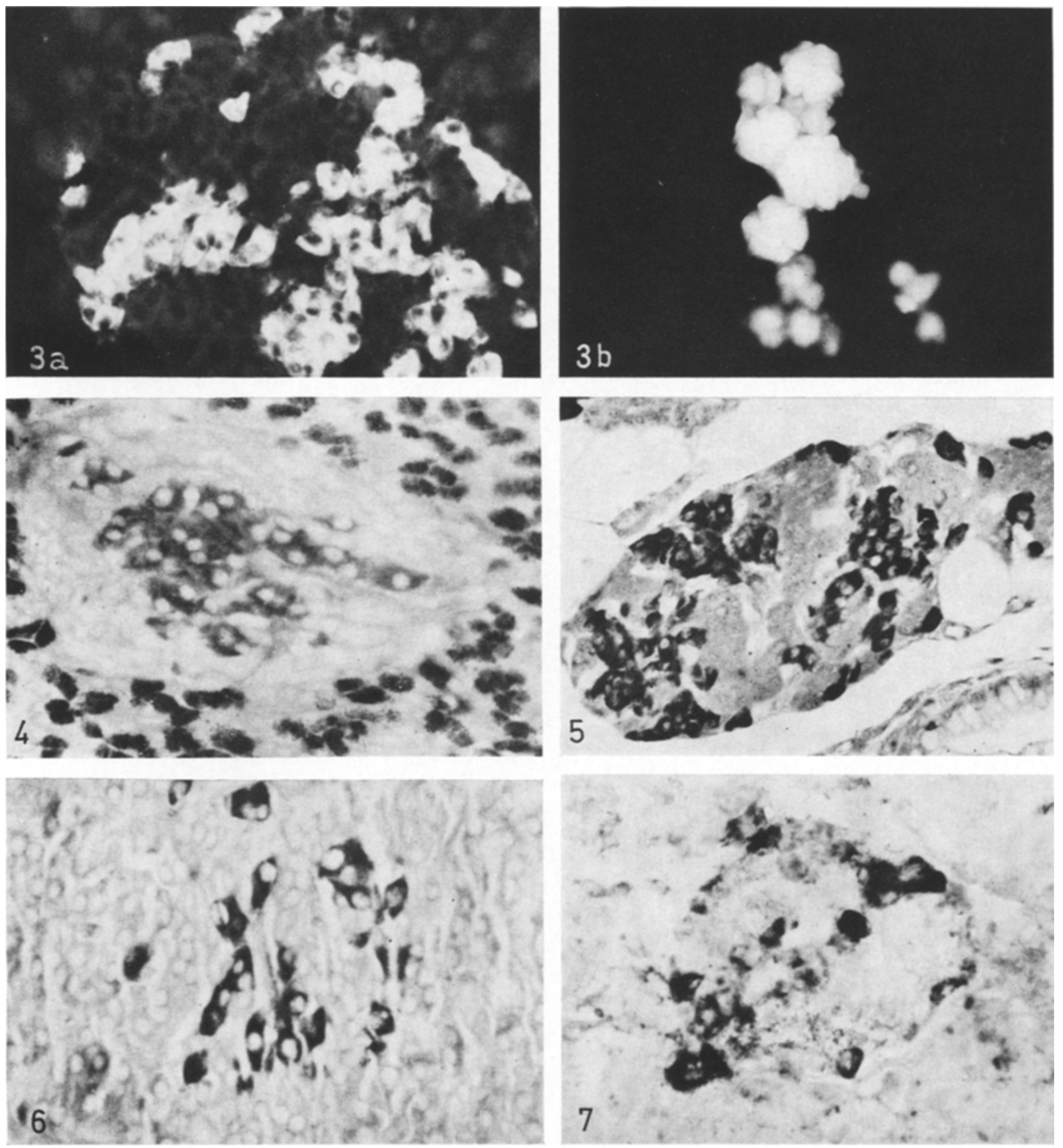

Fig. 3a and b. Formaldehyde-fixed guinea pig pancreas (a; cryostatic section) and glucagon crystals $(b)$ stained with $o$-phthalaldehyde. × 400

Fig. 4. GPA-fixed horse pancreas stained with xanthydrol: A cells blue-gray, B and D cells unreactive, zymogen granules violet. $\mathrm{x} 320$

Fig. 5. Glutaraldehyde-fixed guinea pig pancreas stained with HCl-lead haematoxylin. Reactive cells are A (many) and $D$ cells (few); B cells do not react. $\times 220$

Fig. 6. Bouin-fixed guinea pig pancreas stained with Grimelius' silver. A cells are blackened. $x 360$

Fig. 7. Formaldehyde-fixed human pancreas stained with anti-glucagon antibodies marked with peroxidase. A cells are intensely reactive. $\times 450$ 
and/or peroxidase into pancreatic tissue, immunocytochemical tests in electron microscopy showed that peroxidase linked to anti-glucagon antibodies was selectively bound to the core of $\alpha$ granules.

Table 4. Reactivity of the core and the halo of human $\alpha$ granules to fixing and staining methods at the ultrastructural level

\begin{tabular}{llll}
\hline Fixation & Staining & Core & Halo \\
\hline Osmium & Uranyl-lead & +++ & - \\
Aldehyde-osmium & Uranyl-lead & +++ & + \pm \\
Aldehyde & PT & +++ & + \\
Aldehyde & Grimelius & - & +++ \\
\hline
\end{tabular}
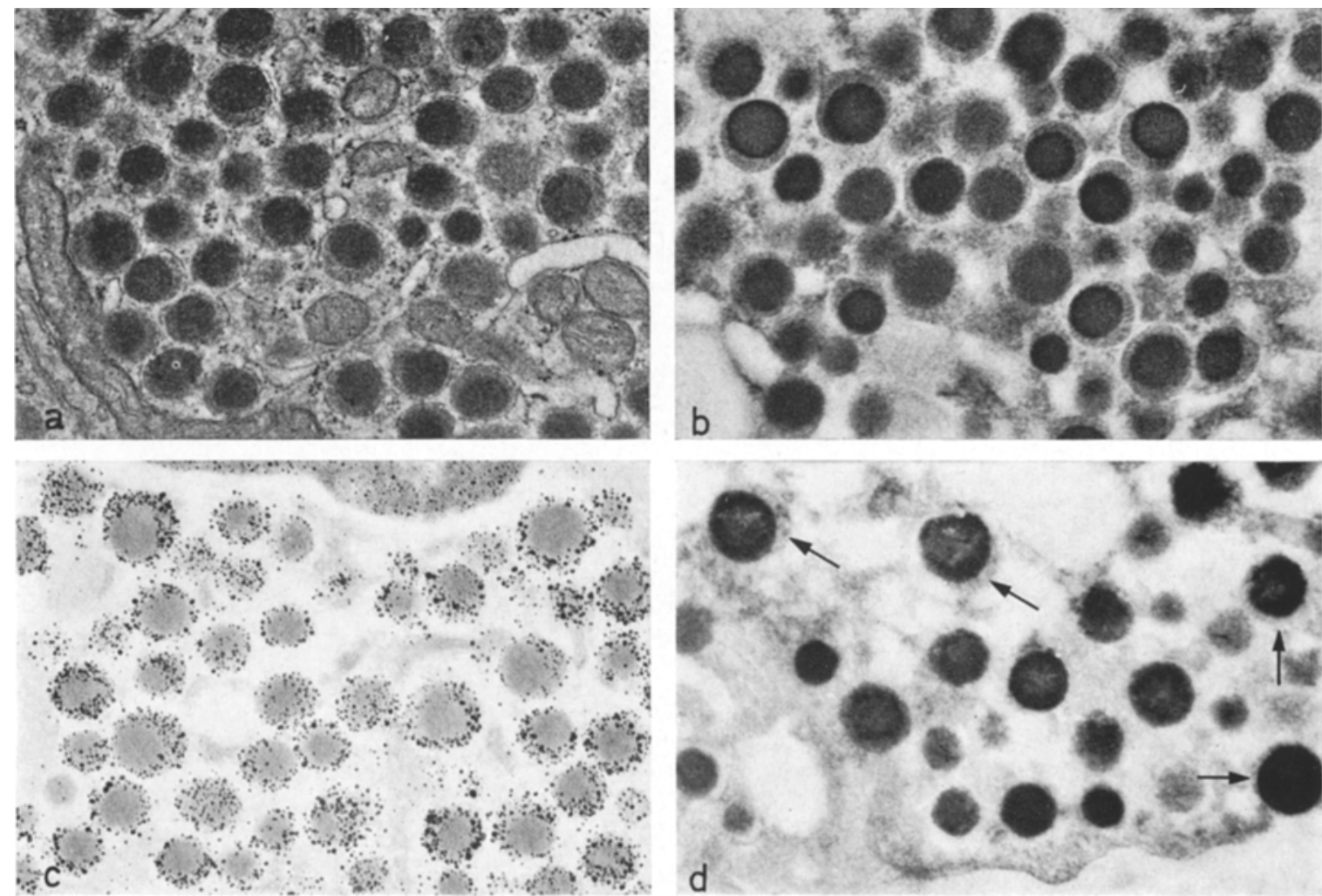

Fig. 8a, b, c and d. Granules of human A cells:

$a$, formaldehyde-glutaraldehyde mixture, osmium, uranyl, lead.

$b$, formaldehyde-glutaraldehyde, phosphotungstic acid.

$c$, formaldehyde-glutaraldehyde, Grimelius' silver, uranyl.

$d$, formaldehyde, antiglucagon antibodies-peroxidase, benzidine, osmium.

The "core" of the granules is heavily stained in $a, b$ and $d$, while it lacks silver grains and is only stained by uranyl in $c$. The "halo" is intensely reactive only to Grimelius' silver. X 24000

\section{Discussion}

These results confirm that only $A$ cells react to antiglucagon sera, whereas $\mathbf{D}$ cells do not react. Thus, although A cells must be considered the source of glucagon, $\mathbf{D}$ cells seem unrelated to this hormone; the exact nature of the hormone they produce remains to be ascertained. er other substances with basic groups are also present in the $\alpha$ granules and contribute to their staining by such methods. The staining by HCl-toluidine blue and HCl-lead-haematoxylin is likely to be mostly due to side-chain protein or polypeptide carboxyls unmasked. by hot $\mathrm{HCl}$; aspartic and glutamic acids "free" carboxyls) as well as asparagine and glutamine (amides) may contribute such groups (Solcia and Sampietro, 
1966; Solcia et al., 1968 and 1969; Pearse, 1969). A total of 7 aspartic acid, glutamine or asparagine residues is represented in the glucagon molecule (Bromer et al., 1956). We do not know whether, besides glucagon, other substances bearing side-chain carboxyls contribute to such stainings.

The above data seem to point to the conclusion that in human A cells glucagon is at least mostly located in the core of $\alpha$ granules, which, according to conventional ultrastructural investigations, should be considered as a definite internal structure of the $\alpha$ granule (Like, 1967; Shibasaki and Ito, 1969). It should be added that in some fishes the core frequently displays a crystalline pattern (Bencosme et al., 1965; Thomas, 1970) similar to that shown by glycagon crystals in vitro (Staub et al., 1955) and that we found some evidence of crystalline structure in the core of a few human granules.

Grimelius' silver behaves quite differently from glucagon-staining methods; thus, the Grimeliuspositive material associated with the $\alpha$ granule "halo" seems to be chemically unrelated to the hormone. As to its exact nature, we have little information. However, it should be noted that its apparent solubility in Carnoy's alcohol-chloroform-acetic acid mixture may be in keeping with the presence of some lipid. component (lipoprotein?). In fact, experiments now in progress suggest binding of silver to ethylene groups of unsaturated fatty acids.

\section{References}

Avrameas, S.: Coupling of enzyme to proteins with glutaraldehyde. Use of the conjugates for the detection of antigens and antibodies. Immunochemistry 6, 43-52 (1969).

Baum, J., Simons, B.E., Unger, R.H., Madison, L.L.: Localization of glucagon in the alpha cells in the pancreatic islet by immunofiuorescent technics. Diabetes 11, 371-374 (1962).

Bencosme, S.A., Liepa, E., Lazarus, S.S.: Glucagon content of pancreatic tissue devoid of alpha cells. Proc. Soc. exp. Biol. Med. 90, 387-392 (1955).

- Meyer, J., Bergman, B.J., Martinez-Palomo, A.: The principal islet of bullhead fish (Ictalurus nebulosus). A correlative light and electron microscopic study of islet cells and of their secretory granules isolated by centrifugation. Rev. canad. Biol. 24, 141-154 (1965).

Bromer, W.W., Sinn, L.G., Staub, A., Behrens, O.K. The amino acid sequence of glucagon. J. Amer. chem. Soc. 78, 3858-3860 (1956).

Bussolati, G., Pearse, A.G.E.: Immunofluorescent localization of the gastrin-secreting $G$ cells in the pyloric antrum of the pig. Histochemie 21, 1-4 (1970).

- Rost, F.W.D., Pearse, A.G.E.: Fluorescence metachromasia in polypeptide hormone-producing cells of the APUD series, and its significance in relation to the structure of the precursor protein. Histochem. J. 1, $517-530(1969)$.

Caramia, F., Munger, B., Lacy, P.E.: The ultrastructural basis for the identification of cell types in the pancreatic islets. I. Guinea pig. Z. Zellforsch. 67, 533-546 (1965).

Cavallero, C., Solcia, E.: On the duplicity of the non-B cells of the pancreatic islets. Symp. Dtsch. Ges. Endokr. $14,257-261$ (1968).
- - Sampietro, R.: Selective histochemistry of glucagon in the A cells of pancreatic islets by indole methods. In: Pharmacology of Hormonal Polypeptides and Proteins, p. 387. Eds. Back, N., Martini, L., Paoletti, R. New York: Plenum Press 1968.

Davies, H.G., In: Gratzer, W.B., Beaven, G.H., Rattle, H.W.E., Bradbury, E.M.: A conformational study of glucagon. Europ. J. Biochem. 3, 276-283 (1968).

Graham, R.C., Karnovsky, M.J.: The early stages of absorption of injected horseradish peroxidase in the proximal tubules of mouse kidney: ultrastructural cytochemistry by a new technique. J. Histochem. Cytochem. 14. $291-302$ (1966)

Grimelius, L.: A silver nitrate stain for $\alpha_{2}$ cells in human pancreatic islets. Acta Soc. Med. upsalien 73, 243-270 (1968).

Hellman, B., Rothman, U., Hellerström, C. : Identification of a specific type of cell located in the central part of the pancreatic islets of the horse. Gen. comp. Endocr. 2, $558-564$ (1962).

Lange, R.: Immunofluoreszenzmikroskopische Darstellung glukagonbildender Zellen an Plastikdünnschnitten von Inselgewebe (Ratte, Frosch). Histochemie 22 $226-233(1970)$.

Levine, H.J., Glenner, G.C.: Observations on tryptophan staining of the pancreatic alpha cells. J. natl. Cancer Inst. 20, 63-68 (1958).

Like, A.A.: The ultrastructure of the secretory cells of the islets of Langerhans in man. Lab. Invest. 16, 937-951 (1967).

Lomsky, R., Langr, F., Vortel, V.: Site of glucagon in the islets of Langerhans of man as studied by the immunofluorescent technic. Sborn. ved. Praci lék. Fak. Hradci Kralové 11, 585-590 (1968).

Luft, J.: Improvements in epoxy resin embedding mothods. J. biophys. biochem. Cytol. 9, 409-414 (1961).

Mason, T.E., Phifer, R.F., Spicer, S.S., Swallow, R.A., Dreskin, R.B.: An immunoglobulin-enzyme bridge method for localizing tissue antigens. J. Histochem. Cytochem. 17, 563-569 (1969).

Okada, N., Takaki, R., Kitagawa, M.: Histologic and immunofluorescent studies on the site of origin of glucagon in mammalian pancreas. J. Histochem. Cytochem. 16, 405-409 (1968).

Pearse, A. G. E. : Random coil conformation of polypeptide hormone precursor protein in endocrine cells. Nature 221, $1210-1211$ (1969).

Petersson, B., Hellmann, B.: Effects of long term administration of glucagon on the pancreatic islet tissue of rats and guinea-pigs. Acta endocr. (Kbh.) 44, 139$149-(1963)$

Scott, H.R.: Rapid staining of beta cell granules. Stain Technol. 27, 267-268 (1952).

Shibasalki, S., Ito, T.: Eloctron microscopic study on the human pancreatic islets. Arch. histol. jap. 31, 119-154 (1969).

Solcia, E., Capella, C., Vassallo, G.: Lead-haematoxylin as a stain of endocrine cells. Significance of staining and comparison with other selective methods. Histochemie 20, 116-126 (1969).

- Sampietro, R.: Cytologic observations on pancreatic islets with reference to some endocrine-like cells of the gastrointestinal mucosa. $Z$. Zellforsch. 68, 689-698 (1965).

- - Sulla natura chimica dei granuli basofili delle cellule enterocromaffini e di alcune cellule endocrine argentofile. Riv. Istoch. norm. pat. 12, 122-123 (1966).

- Capella, C.: Differential staining of catecholamines, 5-hydroxytryptamine and related compounds in aldehyde-fixed tissues. Histochemie 17, 273-283 (1969a).

- Vassallo, G., Capella, C. : Selective staining of endocrine cells by basic dyes after acid hydrolysis. Stain Technol. $43,257-263$ (1968). 
Staub, B., Sinn, I., Behrens, O.K.: Purfication and crystallization of glucagon. J. biol. Chem. 214, 619-632 (1955).

Takaya, K.: A new fluorescent stain with o-phthalaldehyde for A cells of the pancreatic islets. J. Histochem. Cytochem. 18, 178-186 (1970).

Terner, J.Y., Gurland, J., Gaer, F.: Phosphotungstic acid-hematoxylin; spectrophotometry of the lake in solution and in stained tissue. Stain Technol. 39, 141 153 (1964).

Thomas, N.W.: Morphology of endocrine cells in the islet tissue of the cod Gadus callarias. Acta endocr. (Kbh.) 63, 679-695 (1970)

Venable, J.H., Coggeshall, R.: A simplified lead citrate stain for use in electron microscopy. J. Cell Biol. 25, $407-408(1965)$.

Vassallo, G., Capella, C., Solcia, E. : Grimelius' silver stain for endocrine cell granules, as shown by electron microscopy. Stain Technol. 46, 7-13 (1971).

Dr E. Solcia

Istituto di Anatomia ed

Istologia, Patologica

Università di Pavia

Via Forlanini 16

I-27 100 Pavia

Italia 